\title{
Analisis Kemampuan Representasi Matematis Siswa
}

\author{
Ari Suningsih ${ }^{*}$, Ana Istiani ${ }^{2}$ \\ Program Studi Pendidikan Matematika, Universitas Muhammadiyah Pringsewu \\ Jalan KH. Ahmad Dahlan Pringsewu, Lampung, Indonesia \\ 1*ari.suningsih@umpri.ac.id; ${ }^{2}$ anaistani@umpri.ac.id
}

Artikel diterima: 28-01-2021, direvisi: 10-05-2021, diterbitkan: 31-05-2021

\begin{abstract}
Abstrak
Permasalahan dalam riset ini merupakan rendahnya hasil ulangan harian siswa yang disebabkan oleh rendahnya keterampilan representasi matematis siswa. Riset ini ialah riset deskriptif dengan memanfaatkan instrumen berbentuk soal uji yang berupa soal penjelasan serta pedoman wawancara. subjek penelitian berjumlah 23 orang siswa, penerapan pembelajaran di lakukan secara daring di masa pandemi Covid-19. Instrumen riset di bagikan melalui whatsapp grup, serta wawancara dicoba lewat via telpon. Informasi yang diperoleh dianalisis buat mengenali keahlian representasi matematis siswa. Menurut hasil analisis lembar jawaban serta wawancara dari 23 siswa diperoleh kesimpulan jika ketercapain siswa pada indikator representasi visual 65,2\%; indikator representasi ekspresi maupun persamaan 43,5\%; dan indikator representasi kata-kata $41,2 \%$. Hal ini menunjukkan bahwa kemampuan representasi matematis siswa masih perlu diperhatikan untuk dapat ditingkatkan.

Kata Kunci: Hasil Belajar, Keterampilan Representasi Matematis, whatsapp grup.
\end{abstract}

\section{Analysis of Students' Mathematical Representation Ability}

\begin{abstract}
The problem in this research is the low results of students' daily tests caused by the low mathematical representation skills of students. This research is descriptive research using an instrument in the form of test questions in the form of explanatory questions and interview guidelines. The research subjects were 23 students, the application of learning was carried out online during the Covid-19 pandemic. The research instrument was distributed via WhatsApp group, and interviews were tried via telephone. The information obtained was analyzed to identify students' mathematical representation skills. According to the results of the analysis of the answer sheets and interviews of 23 students, it was concluded that the student's achievement in the visual representation indicator was 65.2\%; representation indicators of expressions and equations 43.5\%; and indicators of representation of words $41.2 \%$. This shows that the mathematical representation ability of students still needs to be considered so that it can be improved.

Keywords: Learning Outcomes, Mathematical Representation Ability, WhatsApp Grup.
\end{abstract}




\section{Pendahuluan}

harusnya dikuasai oleh setiap individu karena matematika memiliki peran yang sangat penting dalam dunia pengetahuan dan teknologi. Penguasaan ilmu matematika perlu dilakukan semenjak awal pendidikan seorang anak (Ainy, Shoffa, \& Soemantri, 2019). Seseorang anak yang sudah masuk jenjang pembelajaran formal di sekolah butuh menemukan perlakuan spesial dalam perkembangannya menekuni matematika (Rahman, 2017).

Keahlian yang dihasilkan dari menekuni matematika tersebut menciptakan keahlian berfikir logis, sistematis, inovatif, kreatif (Vernia, 2019; Lestari, 2020) serta lain-lain yang jadi dasar buat menciptakan inovasi didalam pertumbuhan ilmu pengetahuan serta teknologi. Guna mewujudkan harapan tersebut hingga tiap siswa butuh dibekali keterampilan matematis yang matang (Saragih, 2019) supaya nantinya bisa mengintegrasi kemahiran matematis mereka kedalam disiplin pengetahuan yang lain. Kedudukan guru serta lembaga pembelajaran sangat dibutuhkan dalam meningkatkan kepiawaian matematis siswa selaku siswa (Yuniarti, 2016).

Keberadaan pembelajaran yang sangat berarti tersebut, terintegrasi dalam pendidikan di sekolah. Salah satu mata pelajaran yang wajib dipelajari siswa yakni matematika. Matematika menggambarkan ilmu yang diperlukan diberbagai bidang, baik dalam matematika itu sendiri ataupun dalam bidang yang lain (Septian \& Komala, 2019). Secara mendasar, matematika mempunyai peranan berarti dalam bidang pembelajaran (Umar, 2016; Luritawaty, 2018). Hal itu terlihat dari matematika diajarkan pada jenjang pendidikan dasar, pendidikan menengah dan tingkat perguruan tinggi. Dalam mempelajari matematika, peserta didik dituntut untuk mencapai kompetensi yang telah ditetapkan dalam kurikulum.

Salah satu tujuan matematika pada kurikulum 2013 sebagaimana termuat dalam lampiran Permen No.58 Tahun 2014 bagian Pedoman Mata Pelajaran Matematika adalah memahami konsep matematika yang merupakan kompetensi dalam menjelaskan keterkaitan antarkonsep dan menggunakan konsep maupun algoritma secara luwes, akurat, efisien, dan tepat dalam pemecahan masalah. Adapun salah satu indikator pencapaian kompetensi tersebut adalah menyajikan konsep dalam berbagai macam bentuk representasi matematis berupa tabel, grafik, diagram, gambar, sketsa, model matematika, atau cara lainnya (Permendikbud, 2014).

Sejalan dengan hal tersebut, menurut National Council of Teacher Mathematics (NCTM) (Lindquist \& Gates, 2020) ada lima standar proses pembelajaran matematika yang harus dikuasai peserta didik yaitu (1) Belajar untuk memecahkan masalah (mathematical problem solving); (2) Belajar untuk bernalar dan bukti (mathematical reasoning and proof); (3) Belajar untuk berkomunikasi (mathematical communication); (4) Belajar untuk mengaitkan ide (mathematical connection); dan (5) Belajar untuk mempresentasikan (mathematical presentation). Pada mulanya hanya terdapat 4 standar dalam proses pembelajaran matematika yang direkomendasikan di dalam NCTM yaitu kemampuan pemecahan masalah, kemampuan penalaran, kemampuan 
komunikasi, dan kemampuan koneksi matematis. Representasi masih dianggap sebagai bagian dari komunikasi matematis (Duval, 2017; Damayanti \& Afriansyah, 2018). Namun pada kenyataanya, kemampuan representasi matematis juga merupakan suatu hal yang selalu muncul ketika mempelajari matematika pada semua tingkatan pendidikan, sehingga dipandang bahwa representasi merupakan suatu komponen yang layak diperhatikan. Dengan demikian representasi matematis perlu mendapat penekanan dan dimunculkan dalam proses pengajaran matematika sekolah (Goldin, 2020). Representasi adalah bentuk interpretasi pemikiran peserta didik terhadap suatu masalah, yang digunakan sebagai alat bantu untuk menemukan solusi dari masalah tersebut (Sabirin, 2014; Lisarani \& Qohar, 2021). Kemampuan representasi matematis merupakan salah satu tujuan umum dari pembelajaran matematika di sekolah. Kemampuan ini sangat penting bagi peserta didik dan erat kaitanya dengan kemampuan komunikasi dan pemecahan masalah. Seseorang perlu representasi baik berupa gambar, grafik, diagram, maupun bentuk representasi lainnya untuk dapat mengomunikasikan sesuatu (Lette \& Manoy, 2019). Kemampuan representasi matematis diperlukan peserta didik untuk menemukan dan membuat suatu alat atau cara berpikir dalam mengomunikasikan gagasan matematis dari yang sifatnya abstrak menuju konkret, sehingga lebih mudah untuk dipahami (Lette \& Manoy, 2019). Sesuatu permasalahan yang dikira rumit serta komplek dapat jadi lebih simpel bila strategi serta pemanfaatan representasi matematika yang digunakan cocok dengan kasus tersebut (Yanni, 2018). Oleh karena itu, pemilihan model representasi yang dimiliki peserta didik sangat berperan dalam pengambilan keputusan strategi pemecahan masalah matematika yang tepat dan akurat. Kemampuan representasi matematika meliputi antara lain: (1) Menciptakan dan menggunakan representasi untuk menyusun, merekam, dan mengomunikasikan ide matematika, (2) Memilih, menggunakan, dan menerjemahkan setiap representasi matematika untuk memecahkan masalah, (3) Menggunakan model penyajian dan menginterpretasikan secara fisik, sosial, dan phenomena matematika. Selain itu, penggunaan representasi juga dapat menjadikan peserta didik untuk mengatur pemikiranya (Ulfa dkk., 2019). Representasi dapat dibedakan menjadi dua bentuk, yakni representasi internal dan representasi eksternal (Samsuddin \& Retnawati, 2018; Romiyansah dkk., 2020).

Representasi internal menggambarkan kegiatan berpikir tentang inspirasi matematika yang membolehkan bayangan seorang bekerja atas dasar inspirasi tersebut (DiSessa, 2018; Gorev, Telegina, Karavanova, \& Feshina, 2018). Sebaliknya representasi eksternal ialah hasil komunikasi maupun konstruksi dari representasi internal (Ott, Brunken, Vogel, \& Malone, 2018) yang bentuknya antara lain: verbal, foto, serta barang konkrit. Dalam pendidikan, lewat representasi eksternal partisipan didik, guru bisa memandang aktifitas berpikir serta menduga apa yang sebetulnya berlangsung 
sebab kedua perihal tersebut ialah representasi internal yang terdapat dalam benak partisipan didik. Dengan demikian, guru bisa melaksanakan langkah yang pas buat bawa partisipan didik dalam belajar (Silaen, Sudjito, \& Sudarmi, 2019).

Dalam menangkap informasi dari guru, terdapat metode siswa dengan mencermati pemahaman dari guru saja mereka bisa dengan gampang memahaminya, terdapat siswa yang sanggup menangkap informasi dengan trik menuliskannya dipapan tulis, serta terdapat pula siswa yang dapat dengan metode kedua- duanya. Tiap siswa memiliki metode tertentu dalam menangkap informasi yang di informasikan oleh guru. Sehingga, guru memiliki kedudukan berarti dalam menyatakan informasi kepada siswa sehingga siswa bisa dengan gampang buat menguasai data yang diberikan dan menkonstruksikan kembali informasi yang sudah meraka bisa. Pendidikan matematika di kelas masih banyak yang menekankan uraian anak didik tanpa membagikan peluang kepada siswa buat berusaha bermacam berbagai representasi dalam menguasai sesuatu konsep. Anak didik tidak diberi peluang menciptakan jawaban maupun metode yang berbeda dari yang telah diajarkan guru. Guru kerap tidak membagikan peluang kepada anak didik mengkontruksi komentar maupun pemahamannya sendiri terhadap konsep matematika.

Berdasarkan hasil observasi yang dilakukan di SMP Negeri 3 Sukoharjo peneliti mendapakan informasi bahwa hasil belajar siswa kelas VIII semester genap tahun ajaran 2019/2020 masih rendah, karena masih banyak siswa yang mengalami kesulitan dalam membuat gambar bangun segitiga berdasarkan masalah yang diberikan,serta kesulitan pada proses penyelesaian, siswa masih bingung harus menggunakan model persamaan Teorema Pytagoras mana yang tepat untuk menyelesaikan soal yang mereka kerjakan. Pandemi covid-19 menyebabkan pembelajaran matematika dilaksanakan secara daring. Guru melaksanakan pembelajaran daring menggunakan grup whatsapp. Saat sebelum pembelajaran diawali, guru terlebih dulu membuat group belajar partisipan didik spesial mata mata pelajaran matematika. Sesudah itu, guru memberikan modul pelajaran serta tata metode pembelajaran sepanjang aktivitas pendidikan online lewat tim kelas satu hari saat sebelum pembelajaran dilaksanakan ataupun pada disaat hendak diawali pembelajaran. Sesudah itu, guru membagikan waktu kepada partisipan didik untuk menekuni modul secara individual di rumah tiap- tiap. Setelah itu, guru membagikan tugas buat dikerjakan. Metode belajar individual di rumah membuat partisipan didik wajib lebih extra menguasai serta menerima pelajaran yang sudah diberikan guru tanpa dicermati langsung oleh guru.

Hal ini diperoleh dari data hasil ulangan harian siswa kelas VIII dimana hanya 22,5 \% siswa yang mencapai KKM, dengan besaran nilai KKM untuk mata pelajaran matematika yaitu 68. Sebagaimana dapat dilihat pada Tabel 1 berikut ini:

Tabel 1.

Data Hasil Ulangan Harian Siswa Kelas VIII SMP Negeri 3 Sukoharjo

\begin{tabular}{ccccc}
\hline No & Nilai & Jumlah & $\%$ & Kriteria \\
\hline 1. & $68 \leq x \leq 100$ & 17 & $22,5 \%$ & Tuntas
\end{tabular}




\begin{tabular}{|lllll|}
\hline 2. & $0 \leq x<68$ & 57 & $77,5 \%$ & $\begin{array}{l}\text { Tidak } \\
\text { tuntas }\end{array}$ \\
\hline & Jumlah & 74 & $100 \%$ & \\
\hline
\end{tabular}

Sumber: Data Hasil Ulangan Harian Siswa Kelas VIII. SMP Negeri 3 Sukoharjo

Dari data di atas dapat dilihat bahwa siswa yang belum tuntas dari Kriteria Ketuntasan Minimum (KKM) yang telah ditetapkan masih banyak Dari Tabel 1 data yang diperoleh peneliti dapat dilihat bahwa hasil yang diperoleh siswa masih banyak yang dibawah KKM, dengan jumlah siswa kelas VIII 74 yang tuntas KKM 22.5\% dan siswa yang tidak tuntas $77.5 \%$ dalam hal ini bisa disimpulkan bahwa terdapat masalah dalam siswa yang belum mampu menyelesaikan soal Teorema Pyhtagoras.

\section{Metode}

Penelitian ini dilaksanakan di SMP Negeri 3 Sukoharjo yang terletak dikecamatan Sukoharjo, pekon waringinsari barat kecamatan sukoharjo kabupaten pringsewu. Pelaksanaan penelitian dilakukan pada kelas VIII C semester genap tahun ajaran 2019/2020. Informan pada penelitian ini adalah siswa siswi kelas VIII.C SMP Negeri 3 Sukoharjo yang berjumlah 23 siswa.

Dalam penelitian ini wawancara digunakan untuk mencocokan (mengklarifikasi) jawaban yang ada dilembar jawaban dengan apa yang dipahami siswa. Wawancara dilaksanakan secara mendalam untuk dianalisis kemampuan representasi matematisnya berdasarkan hasil belajar pada tes kemampuan representasi matematis.

Wawancara dilakukan melalui media telpon dikarnakan adanya covid-19 sehingga wawancara tidak dapat dilakukan secara langsung untuk mencegah dan memutus mata rantai penyebaran covid19. Dalam penelitian ini soal digunakan untuk mengukur seberapa kemampuan representasi matematis siswa dalam menyelesaikan soal tes teorema pythagoras. Soal diberikan kepada siswa melalui media whatsapp grup dikarnakan adanya covid-19 sehingga pemberiaan dan pengerjaan soal tidak dapat dilakukan secara langsung hal ini dilakukan untuk mencegah dan memutus mata rantai penyebaran covid-19.

\section{Hasil dan Pembahasan}

Berdasarkan hasil analisis lembar jawaban dan wawancara kemampuan representasi matematis pada soal nomor 1 dan nomor 2 maka ketercapaian siswa pada indikator berkemampuan representasi visual berjumlah 15 siswa jika dipersentasikan 65.2\%, ketercapaian siswa pada indikator berkemampuan representasi persamaan atau ekspresi matematis berjumlah 10 siswa, jika dipersentasikan 43.5\%, ketercapaian siswa pada indikator berkemampuan representasi kata-kata berjumlah 9 siswa, jika dipersentasikan 41.2\%.

Tabel 2.

Analisis Data Hasil Tes

\begin{tabular}{|c|c|c|c|c|}
\hline \multirow{2}{*}{$\begin{array}{l}\text { Nomor } \\
\text { Absen }\end{array}$} & \multirow{2}{*}{$\begin{array}{c}\text { Nomor } \\
\text { soal }\end{array}$} & \multicolumn{3}{|c|}{ Indikator } \\
\hline & & 1 & 2 & 3 \\
\hline \multirow[t]{2}{*}{01} & 1 & $\mathrm{~V}$ & $\mathrm{~V}$ & V \\
\hline & 2 & $V$ & V & \\
\hline \multirow[t]{2}{*}{02} & 1 & $\sqrt{ }$ & & \\
\hline & 2 & & & \\
\hline \multirow[t]{2}{*}{03} & 1 & V & V & V \\
\hline & 2 & V & V & V \\
\hline 04 & 1 & & & \\
\hline
\end{tabular}




\begin{tabular}{|c|c|c|c|c|}
\hline & 2 & & & \\
\hline \multirow[t]{2}{*}{05} & 1 & V & V & $V$ \\
\hline & 2 & V & $V$ & $\mathrm{~V}$ \\
\hline \multirow[t]{2}{*}{06} & 1 & V & & \\
\hline & 2 & $V$ & & \\
\hline \multirow[t]{2}{*}{07} & 1 & V & $V$ & $V$ \\
\hline & 2 & $\mathrm{~V}$ & $\mathrm{~V}$ & \\
\hline \multirow[t]{2}{*}{08} & 1 & V & V & V \\
\hline & 2 & $\mathrm{~V}$ & $\mathrm{~V}$ & $\mathrm{~V}$ \\
\hline \multirow[t]{2}{*}{09} & 1 & & & \\
\hline & 2 & & & \\
\hline \multirow[t]{2}{*}{10} & 1 & V & & \\
\hline & 2 & $V$ & & \\
\hline \multirow[t]{2}{*}{11} & 1 & V & $V$ & 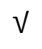 \\
\hline & 2 & $\mathrm{~V}$ & $\mathrm{~V}$ & $\mathrm{~V}$ \\
\hline \multirow[t]{2}{*}{12} & 1 & V & & \\
\hline & 2 & V & & \\
\hline \multirow[t]{2}{*}{13} & 1 & & & \\
\hline & 2 & & & \\
\hline \multirow[t]{2}{*}{14} & 1 & $V$ & 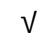 & $\mathrm{V}$ \\
\hline & 2 & $\mathrm{~V}$ & $\mathrm{~V}$ & $\mathrm{~V}$ \\
\hline \multirow[t]{2}{*}{15} & 1 & V & $V$ & V \\
\hline & 2 & V & V & $V$ \\
\hline \multirow[t]{2}{*}{16} & 1 & $\mathrm{~V}$ & & \\
\hline & 2 & V & & \\
\hline \multirow[t]{2}{*}{17} & 1 & $\mathrm{~V}$ & V & $V$ \\
\hline & 2 & V & $\mathrm{V}$ & $\mathrm{V}$ \\
\hline \multirow[t]{2}{*}{18} & 1 & $V$ & V & \\
\hline & 2 & & & \\
\hline
\end{tabular}

Berdasarkan uraian tersebut dapat disimpulkan bahwa berkemampuan representasi visual siswa sudah baik karena ketercapaian siswa pada indikator ini sebesar 65.2\%. Kemampuan representasi visual berupa kemampuan siswa dalam menyajikan jawaban dalam bentuk diagram, tabel atau grafik.

Hasil kemampuan pada pada representasi verbal atau kemampuan siswa dalam membuat 1) situasi masalah berdasarkan data atau representasi yang diberikan, 2) Siswa menuliskan interpretasi atau suatu representasi, 3) Siswa menuliskan langkah-langkah penyelesaian masalah matematika dengan kata-kata. 4) Siswa menyusun cerita yang sesuai dengan suatu representasi yang disajikan. 5) Menjawab soal dengan menggunakan katakata atau teks tertulis. ketercapaian yang yang diperoleh siswa masih lemah yaitu hanya sebesar $41.2 \%$. Hal ini sesuai dengan penelitian (Utami dkk., 2020) yang menyatakan bahwa kemampuan representasi visual siswa SMP Negeri 1 Kunduran sangat baik, sedangkan kemampuan verbal siswa masih sangat kurang. Akan tetapi, penelitian tersebut juga memperoleh hasil berbeda pada kemampuan representasi persamaan atau ekspresi matematis siswa. Pada penelitian ini, diperoleh kemampuan representasi ekspresi matematis siswa masih lemah. Kemampuan represntasi ekspresi meliputi kemampuan dalam membuat persamaan atau model matematika dari representasi lain yang diberikan serta Siswa menyelesaikan masalah dengan melibatkan ekspresi matematis.

Pada penelitian ini, terlihat bahwa kurangnya pengetahuan dan pemahaman konsep berpengaruh pada representasi matematis yang dimiliki oleh siswa. ukakan intelegensi berpengaruh terhadap representasi matematika (Inayah \& Nurhasanah, 2019). Seseorang yang mempunyai intelegensi tinggi memiliki analogi yang matang untuk merepresentasikan suatu masalah. Dengan kata lain, ketika seseorang mempunyai intelegensi yang baik, dia akan mampu merepresentasikan suatu masalah dengan baik pula (Nurpadilah, Rohaeti, \& Afrilianto, 2017). 
Dalam merepresentasikan suatu masalah tentu berkaitan dengan pengetahuan dan pemahaman siswa tentang suatu konsep yang diketahui sebelumnya (Purnama, 2019). Sehingga ketika siswa belum memahami suatu konsep, maka keberhasilan siswa dalam merepresentasikan suatu masalah menjadi kurang tepat. Representasi dalam pembelajaran matematika dapat membantu siswa membangun kemampuan pemahaman dan memberikan gambaran sejauhmana siswa memahami konsep suatu materi matematika (Purnama, 2019).

Selain itu, peneliti melihat bahwa siswa cenderung menggunakan representasi visual dan ekspresi matematis dalam menyelesaikan soal. Hal ini sesuai dengan hasil penelitian Cahdriyana, Sujadi, \& Riyadi (2014: 632-642) yang menunjukkan bahwa siswa SMP Negeri 9 Yogyakarta cenderung menggunakan representasi simbolik dalam menyelesaikan soal SPLDV. Hasil penelitian menunjukkan bahwa 4 siswa yang merepresentasikan langkah -langkah penyelesaian masalah SPLDV dengan representasi simbolik. Sedangkan 2 siswa menggunakan representasi visual dan representasi simbolik.

Kecenderungan siswa memakai representasi visual serta ekspresi matematis dalam menanggapi soal pula dipengaruhi oleh representasi yang disajikan guru pada disaat membagikan modul soal cerita teorema pytagoras (Sulistyowaty, Kesumah, \& Priatna, 2019).

Siswa hanya berpatokan pada apa yang diberikan oleh guru pada dikala pendidikan, sehingga siswa cenderung memakai metode yang sama. Perihal ini menampilkan kalau representasi yang disajikan guru bisa pengaruhi penjelasan siswa dalam menuntaskan permasalahan. Pada saat siswa menguasai sesuatu kiat dalam menuntaskan permasalahan sesuai yang diajarkan oleh guru, sehingga siswa pula hendak memakai metode yang sama dalam menuntaskan soal yang seragam.

Bernilainya kepiawaian representasi matematis siswa serta hendak memutuskan pas ataupun tidaknya strategi yang digunakan dalam menuntaskan soal. Pada saat representasi yang disajikan benar, sehingga strategi yang digunakan untuk mendapatkan jawaban juga benar. Hendak namun kala representasi yang disajikan salah, hingga strategi serta jawaban akhir yang ditemui pula jadi kurang pas. Oleh sebab itu keahlian representasi matematis siswa wajib dikembangkan dengan mengaplikasikan indikator- indikator keterampilan representasi matematis siswa supaya memudahkan siswa dalam menuntaskan soal matematika serta bisa menaikkan keahlian representasi matematis.

Representasi bisa menunjang menggambarkan, memaparkan, ataupun memperluas inspirasi matematika yang meliputi simbol, persamaan, perkata, foto, tabel, grafik, objek manipulatif serta teknik internal berpikir tentang inspirasi matematika. Siswa bisa memperluas uraian inspirasi matematika ataupun hubungan dengan perpindahan dari satu tipe representasi ke representasi yang berbeda dari hubungan yang sama. Tidak hanya itu representasi bisa menggambarkan, mewakili, ataupun melambangkan suatu dalam sesuatu metode. Dengan multiple 
representasi berarti merepresentasikan ulang konsep yang sama dengan format yang berbeda, tercantum verbal, matematik, foto serta grafik. 19 Bagi Cai, Lane serta Jakabesin melaporkan kalau representasi ialah metode yang digunakan seorang buat mengemukakan jawaban ataupun gagasan matematis yang bersangkutan. Macam representasi yang kerap di pakai dalam matematika antara lain tabel, foto, grafik, ekspresi ataupun notasi matematis dan menulis dengan bahasanya sendiri baik forman ataupun informal.

\section{Penutup}

Kesimpulan pada analisis kemampuan representasi matematis siswa dalam menyelesaikan soal teorema pyhtagoras pada setiap indikator kemampuan representasi matematis adalah sebagai berikut: 1) Ketercapaian siswa pada kemampuan representasi visual sebesar 65.2\%; 2) Ketercapaian siswa pada kemampuan representasi persamaan atau ekspresi matematis sebesar $43.5 \%$ atau diperoleh kemampuan representasi ekspresi matematis siswa masih lemah; dan 3) Ketercapaian siswa pada kemampuan representasi verbal sebesar 41,2.

\section{Daftar Pustaka}

Ainy, C., Shoffa, S., \& Soemantri, S. (2019). Lesson Study Sebagai Sarana Meningkatkan Kemampuan Mengajar Dosen dan Kualitas Pembelajaran dalam Perkuliahan Mata Kuliah Kalkulus I. Jurnal Riset Pendidikan Dan Inovasi Pembelajaran Matematika (JRPIPM), $\quad$ 1(2), 82. https://doi.org/10.26740/jrpipm.v1n2. p82-94
Cahdriyana, R. A., Sujadi, I., \& Riyadi, R. (2014). Representasi Matematis Siswa Kelas VII Di SMP N 9 Yogyakarta Dalam Membangun Konsep Sistem Persamaan Linear Dua Variabel. Jurnal Pembelajaran Matematika, 2(6).

Damayanti, R., \& Afriansyah, E. A. (2018). Perbandingan Kemampuan Representasi Matematis Siswa antara Contextual Teaching and Learning dan Problem Based Learning. JIPM (Jurnal IImiah Pendidikan Matematika), 7(1), 30-39.

DiSessa, A. A. (2018). Computational literacy and "the big picture" concerning computers in mathematics education. Mathematical thinking and learning, 20(1), 3-31.

Duval, R. (2017). Understanding the mathematical way of thinking-The registers of semiotic representations. Switzerland: Springer International Publishing.

Goldin, G. A. (2020). Mathematical representations. Encyclopedia of mathematics education, 566-572.

Gorev, P. M., Telegina, N. V., Karavanova, L. Z., \& Feshina, S. S. (2018). Puzzles as a didactic tool for development of mathematical abilities of junior schoolchildren in basic and additional mathematical education. EURASIA Journal of Mathematics, Science and Technology Education, 14(10), em1602.

Inayah, S., \& Nurhasanah, G. A. (2019). Pengaruh Kemampuan Representasi Matematis Siswa Terhadap Kepercayaan Dirinya. Jurnal Penelitian Dan Pembelajaran Matematika, 12(1). https://doi.org/10.30870/jppm.v12i1.4 852

Lestari, P. (2020). Pengembangan Media Pembelajaran Berbasis I-Spring Suite 8 pada Mata Pelajaran Matematika di 
Sekolah Menengah Pertama. Mathline: Jurnal Matematika dan Pendidikan Matematika, 5(1), 1-11.

Lette, I., \& Manoy, J. T. (2019). Representasi Siswa SMP dalam Memecahkan Masalah Matematika Ditinjau dari Kemampuan Matematika. MATHEdunesa, 8(3), 569-575.

Lindquist, M. M., \& Gates, J. D. (2020). National Council of Teachers of Mathematics. Teaching Children Mathematics.

https://doi.org/10.5951/tcm.1.1.0053

Lisarani, V., \& Qohar, A. (2021). Representasi Matematis Siswa SMP Kelas 8 dan Siswa SMA Kelas 10 Dalam Mengerjakan Soal Cerita. Jurnal Magister Pendidikan Matematika (JUMADIKA), 3(1), 1-7.

Luritawaty, I. P. (2018). Pembelajaran take and give dalam upaya mengembangkan kemampuan pemahaman konsep matematis. Mosharafa: Jurnal

Pendidikan Matematika, 7(2), 179-188.

Nurpadilah, E., Rohaeti, E. E., \& Afrilianto, M. (2018). Kemampuan Representasi Matematik Pada Materi Segi Empat Siswa Smp Kelas VII.JPMI (Jurnal Pembelajaran Matematika Inovatif), 1(4), 765-772.

Ott, N., Brünken, R., Vogel, M., \& Malone, S. (2018). Multiple symbolic representations: The combination of formula and text supports problem solving in the mathematical field of propositional logic. Learning and Instruction, 58, 88-105.
Permendikbud. (2014). Permendikbud 79 Tahun 2014. Permendikbud 79 Tahun 2014 Tentang Muatan Lokal K13.

Purnama, R. N. (2019). Analisis Kemampuan Representasi Matematis Siswa Kelas VIII SMP Al Fattah Semarang. Kontinu: Jurnal Penelitian Didaktik Matematika. https://doi.org/10.30659/kontinu.3.1.2 3-36

Rahman, T. (2017). Meningkatkan Disposisi Matematis Siswa dengan Menggunakan Pembelajaran Berbasis Penemuan Terbimbing. PYTHAGORAS: Jurnal Program Studi Pendidikan Matematika.

https://doi.org/10.33373/pythagoras.v $6 i 1.618$

Romiyansah, R., Karim, K., \& Mawaddah, S. (2020). Analisis Kemampuan Koneksi Matematis Siswa Pada Pembelajaran Matematika Dengan Menggunakan Model Pembelajaran Inkuiri Terbimbing. EDU-MAT: Jurnal Pendidikan Matematika, 8(1).

Sabirin, M. (2014). Representasi dalam Pembelajaran Matematika. Jurnal Pendidikan Matematika, 1(2), 33. https://doi.org/10.18592/jpm.v1i2.49

Samsuddin, A. F., \& Retnawati, H. (2018, September). Mathematical representation: the roles, challenges and implication on instruction. In Journal of Physics: Conference Series (Vol. 1097, No. 1, p. 012152). IOP Publishing.

Saragih, M. J. (2019). Perlunya Belajar Mata Kuliah Aljabar Abstrak Bagi Mahasiswa Calon Guru Matematika. Jurnal 
Cendekia: Jurnal Pendidikan

Matematika, 3(2), 249-265.

Septian, A., \& Komala, E. (2019).

Kemampuan Koneksi Matematik dan Motivasi Belajar Siswa dengan Mengunakan Model Problem-Based Learning (PBL) Berbantuan Geogebra di SMP. Prisma, 8(1), 1-13.

Silaen, S. S., Sudjito, D. N., \& Sudarmi, M. (2019). Pengembangan Tes Diagnostik Multi Representasi Eksternal (MRE) untuk Mengetahui Profil Kemampuan Representasi Konsep. Publikasi Pendidikan, 9(2), 98.

Sulistyowaty, R. K., Kesumah, Y. S., \& Priatna, B. A. (2019). Peningkatan Kemampuan Representasi Matematis Melalui Pembelajaran Collaborative Problem Solving. Jurnal Pendidikan Matematika.

https://doi.org/10.22342/jpm.13.2.682 9.153-162

Ulfa, F. M., Asikin, M., \& Dwidayati, N. K. (2019). Membangun Kemampuan Berpikir Kreatif Matematis Siswa dengan Pembelajaran PjBL terintegrasi Pendekatan STEM. Prosiding Seminar Umar, W. (2016). Membangun Kemampuan Komunikasi Matematis Dalam Pembelajaran Matematika. Infinity Journal. https://doi.org/10.22460/infinity.v1i1. 2

Utami, N. A., Murtianto, Y. H., \& Nizaruddin, N. (2020). Profil kemampuan representasi matematis ditinjau dari kemampuan berpikir kritis dan kecerdasan emosional. AKSIOMA: Jurnal Matematika Dan Pendidikan Matematika, 11(2), 274-285.
Vernia, D. M. (2019). Peranan Pembelajaran Matematika Untuk Menumbuhkan Jiwa Berwirausaha Siswa SMK Kota Bekasi. Lectura: Jurnal Pendidikan, 10(1), 47-65.

Yanni, R. P. (2018). Persepsi Mahasiswa PPKn Tentang Pelaksanaan dan Kebijakan Uang Kuliah Tunggal di Universitas Negeri Padang. Journal of Civic Education. https://doi.org/10.24036/jce.v1i1.6

Yuniarti, Y. (2016). Peran Guru Dalam Meningkatkan

Kemampuan Representasi Matematika Dalam Pembelajaran Matematika. EduHumaniora / Jurnal Pendidikan Dasar Kampus Cibiru, 5(1). https://doi.org/10.17509/eh.v5i1.2838

\section{Riwayat Hidup Penulis}

Ari Suningsih, S.Pd, M.Pd.

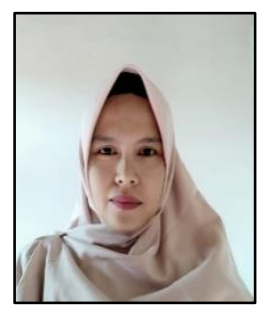

Lahir di Kresnomulyo, 16 Maret 1983. Dosen pada program studi Pendidikan Matematika Universitas Muhammadiyah Pringsewu Lampung, S1 Pendidikan Matematika Pada Universitas Lampung lulus pada tahun 2006. S2 Pendidikan Matematika Pada Unievrsitas Sebelas Maret Surakarta lulus tahun 2014.

\section{Ana Istiani, S.Pd., M.Si.}

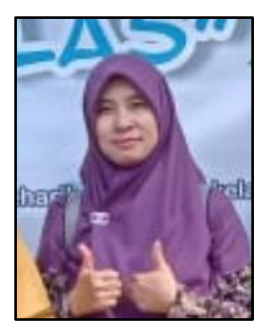

Lahir di Pandansari, 24 Desember 1983, sebagai Staf pengajar di Prodi Pendidikan matematika Universitas Muhammadiyah Pringsewu Lampung. Studi S1 Pendidikan Matematika di STKIP Muhammadiyah Pringsewu Lampung lulus tahun 2006 dan S2 Matematika MIPA lulus Tahun 2015. 